\title{
Morphometry and mixing regime of a tropical lake: Lake Nova (Southeastern Brazil)
}

\author{
MONICA A. GONÇALVES ${ }^{1}$, FÁBIO C. GARCIA ${ }^{2}$ and GILBERTO F. BARROSO ${ }^{2}$ \\ ${ }^{1}$ Agência Estadual de Recursos Hídricos/AGERH, Rua Desembargador José \\ Fortunato Ribeiro, 95, Mata da Praia, 29066-070 Vitória, ES, Brasil \\ ${ }^{2}$ Universidade Federal do Espírito Santo, Departamento de Oceanografia e Ecologia, \\ Avenida Fernando Ferrari, 514, 29075-910 Vitória, ES, Brasil \\ Manuscript received on November 10, 2015; accepted for publication on April 18, 2016
}

\begin{abstract}
Lake Nova $\left(15.5 \mathrm{~km}^{2}\right)$ is the second largest lake in the Lower Doce River Valley (Southeastern Brazil). A better understanding of ecosystem structure and functioning requires knowledge about lake morphometry, given that lake basin form influences water column stratification. The present study aims to contribute to the understanding of relationship between morphometry and mixing patterns of deep tropical lakes in Brazil. Water column profiles of temperature and dissolved oxygen were taken on four sampling sites along the lake major axis during 2011, 2012 and 2013. The bathymetric survey was carried out in July 2011, along $131.7 \mathrm{~km}$ of hydrographic tracks yield 51,692 depth points. Morphometric features of lake size and form factors describe the relative deep subrectangular elongated basin with maximum length of 15.7 $\mathrm{km}$, shoreline development index 5.0 , volume of $0.23 \mathrm{~km}^{3}$, volume development of 1.3 , and maximum, mean and relative depths of $33.9 \mathrm{~m}, 14.7 \mathrm{~m}$ and $0.7 \%$, respectively. The deep basin induces a monomictic pattern, with thermal stratification during the wet/warm season associated with anoxic bottom waters $(1 / 3$ of lake volume), and mixing during dry and cool season. Based on in situ measurements of tributary river discharges, theoretical retention time (RT) has been estimated in 13.4 years. The morphometry of Lake Nova promote long water RT and the warm monomictic mixing pattern, which is in accordance to the deep tropical lakes in Brazil.
\end{abstract}

Key words: lake morphometry, bathymetry, tropical lakes, mixing pattern, geographic information system.

\section{INTRODUCTION}

Morphometric features of lake ecosystems influence several aspects of lake physics, chemistry and ecology. Lake size and form are related to the heat exchanges with the adjacent atmosphere, and therefore with water column mixing pattern. The mixing pattern, in turn, influences spatial and

Correspondence to: Monica Amorim Gonçalves

E-mail: monicaag.amorim@gmail.com temporal variability of hydrochemistry regarding the distribution of nutrients and dissolved gases. Wind work on the lake surface may influence mixing depths, as well as sediments resuspension on shallow areas, reducing water transparency. Hydrodynamics of tributary rivers pondered with lake volume yield the retention time, which in turn control mass balance of substances, such as contaminants. Therefore, lake morphometry indirectly controls biological activity, primary and 
secondary productivity, and the overall lake trophic state (Håkanson 2005).

In Brazil, lake morphometry studies are relative incipient with emphasis on artificial lakes for management purposes of hydropower generation. In contrast, natural lakes are seldom investigated regarding their morphometric features. The work by Schwarzbold and Schäfer (1984) is the most comprehensive comparing basic morphometry parameters of 61 coastal lakes of Rio Grande do Sul State. In the Middle Doce River Valley - MDRV (Minas Gerais) there is a lake district with about 158 lakes (Barbosa et al. 2013) with a great variety of size and form, with attention to Lake Dom Helvécio, a deep lake with maximum $\left(Z_{\max }\right)$ and mean $\left(Z_{\text {mv }}\right)$ depths of 39.2 and $11.3 \mathrm{~m}$, respectively (Bezerra-Neto and Pinto-Coelho 2008). These deep Brazilian tropical lakes show a trend for typical warm monomictic systems with anoxic bottom waters during the stratification season (Henry et al. 1989). In the Lower Doce River Valley - LDRV, at the Espírito Santo State, there is a lake district with 90 lakes ranging from 0.8 ha to $62 \mathrm{~km}^{2}$ of surface area, with a total of $165 \mathrm{~km}^{2}$ and distributed into a coastal plain and within alluvial valleys of Barreiras geological formation (Barroso 2007). Some lakes in the alluvial valleys can be considered relatively deep compared to natural Brazilian lakes (mean $\mathrm{Z}_{\text {max }}=11.8 \mathrm{~m}, \mathrm{~N}=30$; mean $\mathrm{Z}_{\mathrm{mv}}=5.1 \mathrm{~m}, \mathrm{~N}=20$ ), with Lake Palmas with maximum and mean depths of 50.7 and $21.3 \mathrm{~m}$, respectively (Barroso et al. 2014).

The present study aims to contribute to the understanding of relationship between morphometry and mixing patterns of deep tropical lakes in Brazil, which seems to show a warm monomictic regime.

\section{MATERIALS AND METHODS}

\section{STUDY AREA}

Lake Nova is a tropical natural lake of the Lower Doce River Valley - LDRV (Linhares, ES, Brazil)
(Figure 1).Regionalgeomorphology is characterized by alluvial plain, coastal plains and plateaus. The plateaus of Barreiras Formation (Tertiary period) are desiccated by alluvial valleys dammed by deposition of fluvial sediments, including material deposited by Doce River (Martin et al. 1996). Recently, evidences of neotectonics have been found with fractures and faults controlling the regional geomorphology of Barreiras Formation with NW-SE orientation of hydrographic network (Hatushika et al. 2007, Bricalli and Mello 2013).

Regional climate is characterized with warm and wet summers and dry and cool winters, with mean annual air temperatures and rainfall of 24.8 ${ }^{\circ} \mathrm{C}$ and $1,177.1 \mathrm{~mm}$, respectively. Mean rainfall for warm and wet and dry and cool seasons are 220.2 and $48.4 \mathrm{~mm}$, respectively (F.A. Mello, unpublished data).

In contrast to the neighboring Lakes Juparanã, Palmas, Palminhas and Terra Alta, there is no fish farming operation (floating cages) in Lake Nova. Major water uses are related to recreational, unregulated water abstraction for irrigation, and boating.

\section{LAKE SURFACE AND WATERSHED DATA}

A geographic information system (GIS) was developed to handle hydrographic and watershed data with ArcGIS 10.1 ESRI ${ }^{\circledR}$ and Universal Transverse Mercator - UTM and datum World Geodetic Datum - WGS 1984. Lake shoreline was screen digitized from an aerial photography, year 2008 in scale of 1:15,000, and spatial resolution of $1 \mathrm{~m}$. A digital elevation model - DEM with $30 \mathrm{~m}$ of spatial resolution has been created after interpolating elevation point data from the Brazilian Institute of Geography and Statistics and data extracted from a DEM raster from NASA Shuttle Mission (90 m of spatial resolution) using 3D tools of ArcGIS 10.1. Watershed delimitation was grounded on the clustering up subbasins with ArcGIS 10.1 Watershed tool, Hydrological toolbox. 


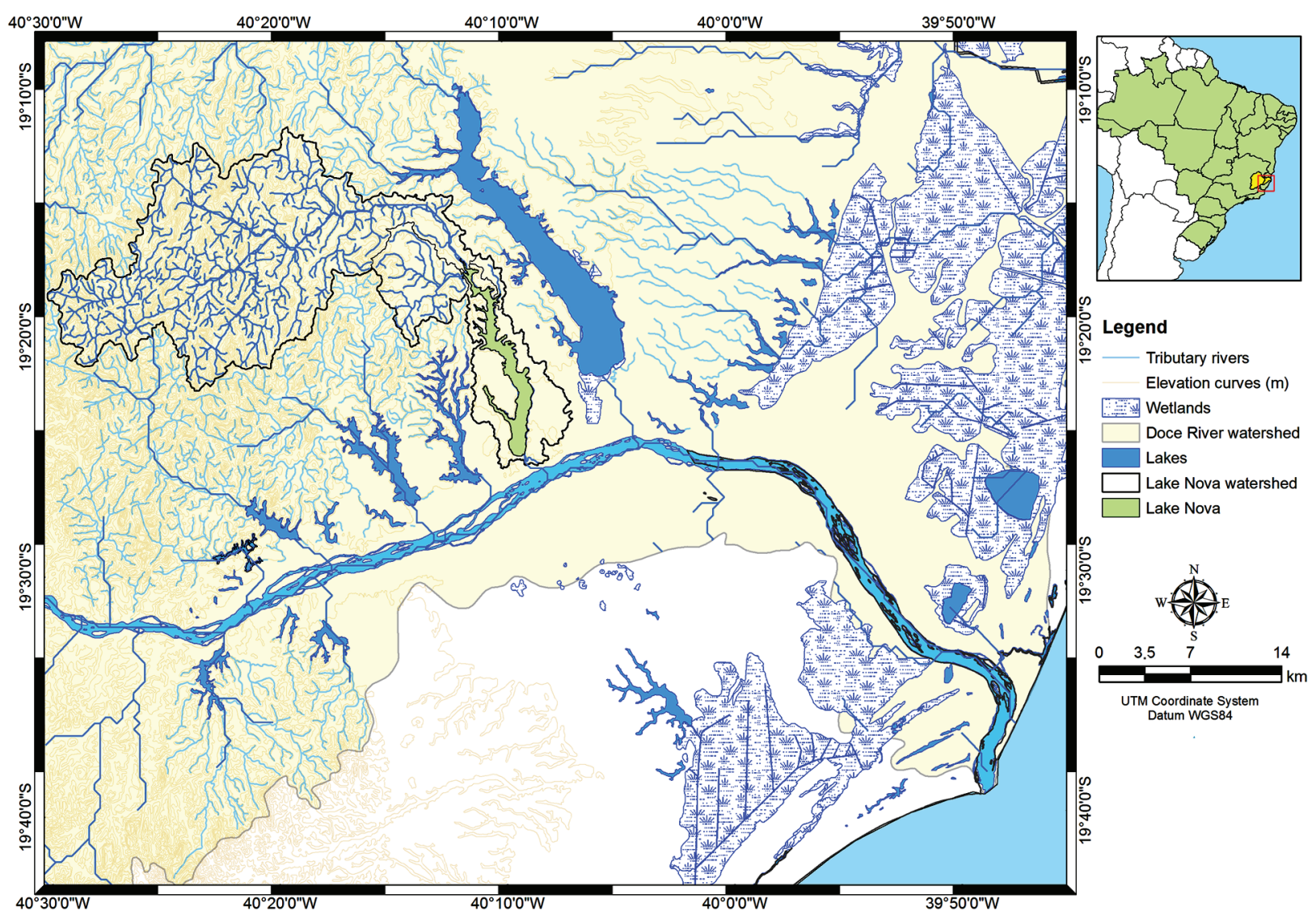

Figure 1 - Lake District in the Lower Doce River Valley (Linhares, ES) and Lake Nova and its watershed.

\section{BATHYMETRIC SURVEY}

Bathymetric survey was carried out in July 2011 with an Ohmex SonarMite BT and DGPS Trimble GeoXH with a real time correction with a Trimble Geobeacon on a grid with transversal tracks of $300 \mathrm{~m}$ distance along the lake axis. Navigation on the sampling grid was oriented with GPS Trimble Juno receiver with ArcPad 7.0 ESRI ${ }^{\circledR}$. Navigation speed was under $5 \mathrm{~km} / \mathrm{h}(2.7$ knots $)$. XYZ data with Easting and Northing coordinates and depth (m), respectively, were converted to a point shapefile, and then edited to remove spike data. Lake shoreline polygon was converted to a point file and each point was assigned as $0 \mathrm{~m}$ depth. This file was later merged with the hydrographic survey points file. Simple kriging was applied to the point data as an interpolation method using
Geostatistical Analyst 10.1 (ArcGIS 10.1, ESRI ${ }^{\circledR}$ ). Semivariogram modeling, bivariate distribution and cross validation done according to Isaks and Srivastava (1989) and Burrough and MacDonnel (1998). A triangular irregular network - TIN model was generated from the lake bathymetric map in order to allow computation of size and special morphometry parameters.

\section{LAKE BASIN MORPHOMETRY}

The accuracy of bathymetric map was evaluated according to Håkanson (2004). The ratio of the lake area $\left(\mathrm{km}^{2}\right)$ and the total distance traveled in transects $(\mathrm{km})$ defines the intensity of the bathymetric survey $\left(\mathrm{L}_{\mathrm{r}}\right)$. The accuracy of the bathymetric map was assessed with the Information Value $(I)$, which is completely correct when $I=1$. In order to determine $I$, one need to define the Correctly Identified Area 
$\left(I^{\prime}\right)$ and the Information Number ( $\left.I^{\prime \prime}\right)$. The latter is dependent from the number of contour lines in the bathymetric map. Assessment of $I, I^{\prime}$ and $I$ "' were according to:

$$
\begin{gathered}
\mathrm{I}=\mathrm{I}{ }^{\prime} * \mathrm{I}^{\prime} \\
I^{\prime}=\left[A-0.14 * L_{r}{ }^{*} L_{d}{ }^{2} *(1 /(n+2))^{0.5} * \Sigma \sqrt{ } A_{i}\right] / A \\
I^{\prime \prime}=\left(e^{0.4 \pi}-1\right) /\left(e^{0.4 \pi}+0.02\right)
\end{gathered}
$$

where:

$A=$ lake area $\left(\mathrm{km}^{2}\right)$

$A_{i}=$ cumulative area $\left(\mathrm{km}^{2}\right)$ within the limits of an specific contour line;

$L_{r}=$ ratio between lake area $\left(A\right.$ in $\left.\mathrm{km}^{2}\right)$ and the effective total distance

surveyed $(\mathrm{km})\left(L_{r}=A / \sum L_{i}\right)$;

$L_{d}=$ normalized lake shore development;

$D_{L}=$ shoreline development index $\left(D_{L}=\left\{L_{0}\right\}\right.$ $[2 *(\sqrt{ } \pi * A)]\})$;

$e=$ the base for natural logarithm, $e=2.718$.

Lake size, form and special factors were calculated according to Håkanson (2004). Symbols for morphometric parameters were according to Hutchinson (1957). Lake size factors, such as lake area $(A)$, shoreline length $\left(L_{0}\right)$, maximum length $\left(L_{\max }\right)$, maximum breadth $\left(B_{\max }\right)$, maximum depth $\left(Z_{\max }\right)$ were calculated from bathymetric data. Volume $(V)$ was calculated with Functional Surface of ArcGIS 10.1, ESRI ${ }^{\circledR}$ 3D Analyst Tools, and the TIN model. Lake form factors were calculated for mean depth $\left(Z_{m v}=V / A\right)$, relative depth $\left(Z_{r}=\right.$ $\left.\left\{50 * Z_{\max } *[(\sqrt{ } \pi) /(\sqrt{ } A)]\right\}\right)$, shoreline development index $\left(D_{L}=\left\{L_{0} /[2 *(\sqrt{ } \pi * A)]\right\}\right)$, volume development index $\left(V_{d}=\left[\left(3 Z_{m v}\right) / Z_{m a x}\right]\right)$ and mean slope $\left(\mathrm{S}_{\mathrm{mv}}\right)$ according to $S_{m v}=\left\{\left(L_{0}+2 * L_{c t o o}\right) * Z_{\max }\right.$ \} $[(2 * n * A)]\}$

where,

$L_{0}=$ the shoreline length in $\mathrm{km}$;

$L_{\text {ctot }}=$ the total length for all contour lines in $\mathrm{km}$ excluding the shoreline;

$Z_{\max }=$ the maximum depth in $\mathrm{m}$; $n=$ the number of contour lines;

$A=$ the lake water surface area in $\mathrm{km}^{2}$.

The $A: V$ and $Z_{m v}: Z_{\max }$ ratios were calculated according to Hutchinson (1957) The ratio of lake area to volume $(A: V)$ provides an indication of potential evaporation and thermal stability of water column, while the $Z_{m v}: Z_{\max }$ ratio describes the basin shape (Hutchinson 1957). The ratio between watershed area $\left(W_{A}\right)$ and lake surface area $(A)$ was calculated.

Among special morphometric factors wave base depth $\left(Z_{w b}\right)$, effective fetch $\left(L_{e f}\right)$, wave height $(H)$, volumes of epilimnion $\left(V_{e p}\right)$, littoral $\left(V_{\text {litt }}\right)$, pelagic $\left(V_{\text {pel }}\right)$, hypoxic $\left(V_{\text {hypox }}\right)$ and anoxic zones $\left(V_{\text {anox }}\right)$, as well as the Index of Basin Permanence (IBP) (Kerekes 1977) and dynamic ratio (DR) (Håkanson 2004) were calculated. $Z_{w b}$ was determined according to $Z_{w b}=[45.7 *(\sqrt{ } A) /$ $(21.4+\sqrt{ } A)]$. To calculate $L_{e f}$ and $H$ for NE (wet and warm season) and SE (dry and cool season) winds a grid of 112 points with a regular distance of $400 \mathrm{~m}$ was set on a lake surface polygon GIS layer. $L_{e f}$ in each site was calculated based on fetch distances from lake shores considering the predominant wind $\left(0^{\circ}\right)$ and every $6^{\circ}$, up to $42^{\circ}$, for both sides of the predominant wind. Distances were integrated according to Beach Erosion Board (1972 in Håkanson 2004) $L_{e f}=\left\{\sum x_{i} \cos \left(a_{i}\right)\right\}$ $\left.\left[\left(\Sigma \cos \left(a_{i}\right)\right) * S C^{\prime}\right]\right\}$, where $\Sigma \cos \left(\mathrm{a}_{i}\right)=13, \mathrm{a}=$ calculation constant, and $\mathrm{SC}^{\prime}=$ scale constant. In this study a scale constant, based on a map with scale of 1:30,000, was 0.3 . Wave height $(H)$ were calculated with $L_{e f}$ on each of the 112 points based on $H=(0.105 * \sqrt{F}(\mathrm{~cm})$, where $F$ is fetch. Surface models for NE and SE $L_{e f}(\mathrm{~km})$ and $H(\mathrm{~m})$ were interpolated in ArcGIS 10.1 using Spline with 0.01 weight, 3 neighborhood points, and cell size of 10 .

$Z_{w b}$ was considered to estimate the volume of epilimnion waters. Delimitation of littoral and pelagic zones and estimating their volumes were based on depth of euphotic zone $\left(Z_{e u}\right)$, calculated from the Secchi disk depth multiplied by 2.7 (Cole 1994). Volumes of anoxic and hypoxic waters (< 
$0.2 \mathrm{mg}$ dissolved oxygen. $\mathrm{L}^{-1}$ ) were based on the depth of water column vertical profiling in the wet and warm season. Cryptic depth $\left(Z_{c}\right)$, which is the depth below mean sea level, and volume were calculated considering the elevation of lake surface above sea level. All volumes were determined with ArcGIS 3D Analyst Tools routines.

The Index of Basin Permanence - IBP (Kerekes 1977) in $\mathrm{m}^{3} \cdot \mathrm{km}^{-1}$, which indicate the influence of littoral zone on lake volume, was calculated with the ratio of lake volume $\left(x 10^{6} \cdot \mathrm{m}^{3}\right)$ and lake shoreline length $(\mathrm{km})\left(I B P=V / L_{0}\right)$. The dynamic ratio $-\mathrm{DR}$, which indicate the influence of turbulence and resuspension of sediments due to wind and waves processes was calculated according to $D R=V A / Z_{m v}$ (Håkanson 2004).

Lake water theoretical retention time $(R T)$ was determined from the ratio of lake volume in $\mathrm{m}^{3}$ by the mean annual flow $\left(Q_{\text {mean }}\right)$ in $\mathrm{m}^{3} \cdot \mathrm{s}^{-1}$ of the three tributary streams (Figure 3 ), $R T=V / Q_{\text {mean }} \cdot Q_{\text {mean }}$ was determined from in situ discharge measurements $(\mathrm{N}=24)$ during wet (November/December/2012 and March/2013) and dry (August/2011, September/2012 and July/August/September/2013) seasons with an YSI Sontek FlowTracker Handheld - Acoustic Doppler Velocimeter (ADV).

\section{WATER COLUMN STRUCTURE}

Forty-four profiles of temperature and dissolved oxygen and Secchi disk depths were recorded on four lake sampling sites on eleven sampling events during warm/wet (December/2011, January/March/ November/December/2012 and March/2013) and dry/cool (July/2011, July/2012, July/August/ September/2013) seasons.

During warm/wet and dry/cool seasons lake samplings were carried out in 4 sampling sites along Lake Nova axis (Figure 3). Vertical profiling for temperature $\left({ }^{\circ} \mathrm{C}\right)$ and dissolved oxygen $\left(\mathrm{mg} \cdot \mathrm{L}^{-1}\right)$ were recorded with a Horiba U-53G with $30 \mathrm{~m}$ cable water quality probe. Mixing depth $\left(Z_{m i x}\right)$ was determined considering the maximum discontinuity of water column relative thermal resistance $(R T R)$ (Dadon 1995).

Thermal resistance of water column was calculated for each sampling site and sampling event using Wedderburn $(W)$ number according to Imberger and Hamblin (1982) and Reynolds (2006). Wind data was acquired from Linhares meteorological station (A614) based on hourly records from 2007 to 2009 (Barroso et al. 2014). $W$ was calculated according to:

$$
W=\left\{\left[D r_{\omega} * g *\left(h_{m}\right)^{2}\right] /\left[r_{\omega} *(u *) * L\right]^{0.5}\right\}
$$

where:

$D r_{\omega}=$ difference of specific water mass from the upper and lower layers of thermocline in $\mathrm{kg} . \mathrm{m}^{-3}$;

$h_{m}=$ thermocline depth in $\mathrm{m}$;

$L=$ effective fetch in m;

$u^{*}=$ wind friction velocity according:

$$
u^{*}=\sqrt{ } \rho_{\text {air }} / \rho_{\text {sur }} * C d * u^{2}
$$

where:

rair: air specific mass in $\mathrm{kg} \cdot \mathrm{m}^{-3}$;

rsur: specific water mass at lake surface in $\mathrm{kg} . \mathrm{m}^{-3}$;

$C d$ : friction coefficient $=0.0014$

$u$ : wind speed in $\mathrm{m} \cdot \mathrm{s}^{-1}$.

When, $W>1$ water column is stable and when $W<1$ water column is unstable and susceptible to mixing by wind forces.

Water transparency was determined with a Secchi disk and the extension of euphotic zone $\left(Z_{e u}\right)$ determined with an underwater light meter system LiCor LI-250A with a LI-193 spherical quantum sensor $\left(\mu \mathrm{mol} \mathrm{s} \mathrm{s}^{-1} \cdot \mathrm{m}^{-2}\right)$. Light limitation for phytoplankton photosynthesis was determined with $Z_{e u}: Z_{m i x}$ ratio (Jensen et al. 1994, Naselli-Flores 2000).

\section{RESULTS}

\section{BATHYMETRIC MAP}

After edition to remove spike data the hydrographic survey yielded 51,692 depth points, collected along 
$131.7 \mathrm{~km}$ as a total distance navigated. The intensity of hydrographic survey $\left(L_{r}\right)$ was $0.11 \mathrm{~km}$, which is suitable for relative small size lakes.

The resulting bathymetric map produced on $1: 60,000$ with a spatial resolution of $22.6 \mathrm{~m}$ is shown on Figures 2 and 3.

The overall map accuracy based on an Information Value $(I)$ of 0.8 was calculated considering a Correctly Identified Area $\left(I^{\prime}\right)$ of 0.9 and an Information Number ( $I$ ") of 0.9. That means with a $5 \mathrm{~m}$ interval of contours lines the percentage of Correctly Identified Area was $88 \%$, with an error of $12 \%$ or $1.8 \mathrm{~km}^{2}$.

\section{LAKE SIZE AND FORM}

Lake Nova lies $22 \mathrm{~m}$ above mean sea level and has a surface area $(A)$ of $15.5 \mathrm{~km}^{2}$, maximum depth $\left(Z_{\max }\right)$ of $33.9 \mathrm{~m}$ and a volume $(V)$ of $0.23 \mathrm{~km}^{3}(2.28$ $\mathrm{x} 10^{8} \mathrm{~m}^{3}$ ) (Table I). The lake basin is subretangular elongated and slightly dendritic oriented N-S, with three inflections towards SE. Three tributary streams on the upper part of the basin feeds the lake, which has a drainage stream at the southernmost shore. Figure 2 show the sequence of generating the main cartographic products, from depth data points, the bathymetric model, the triangular irregular network - TIN, and the bottom slope (\%).

Hypsographic curves show the distribution of area and volume with lake depth. The relative deep and elongated shape of lake basin is described by area and volume curves showing a single inflection point and a slightly convex (SCx) form (Figure 4).

The basin shape can be described by steep shores showing rapid decrease of lake volume and a milder decrease of surface area for increasing depths close to the surface. This shape is also supported with high values of relative depth $\left(Z_{r}\right)$, and volume development index $\left(V_{d}\right)$ (Table I).

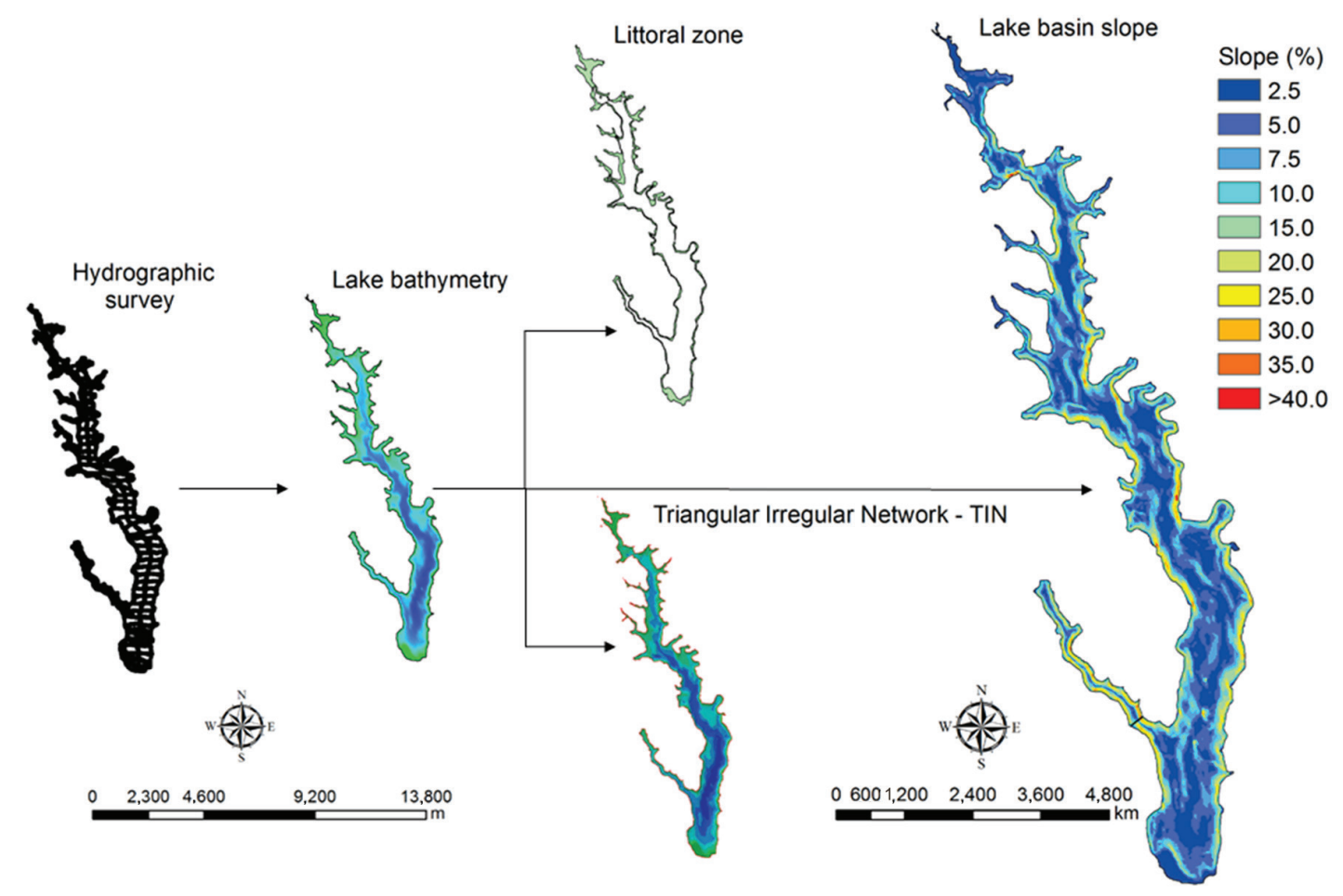

Figure 2 - GIS rasters created from interpolation of depth point data: lake bathymetry, triangular irregular network TIN and basin slope. 


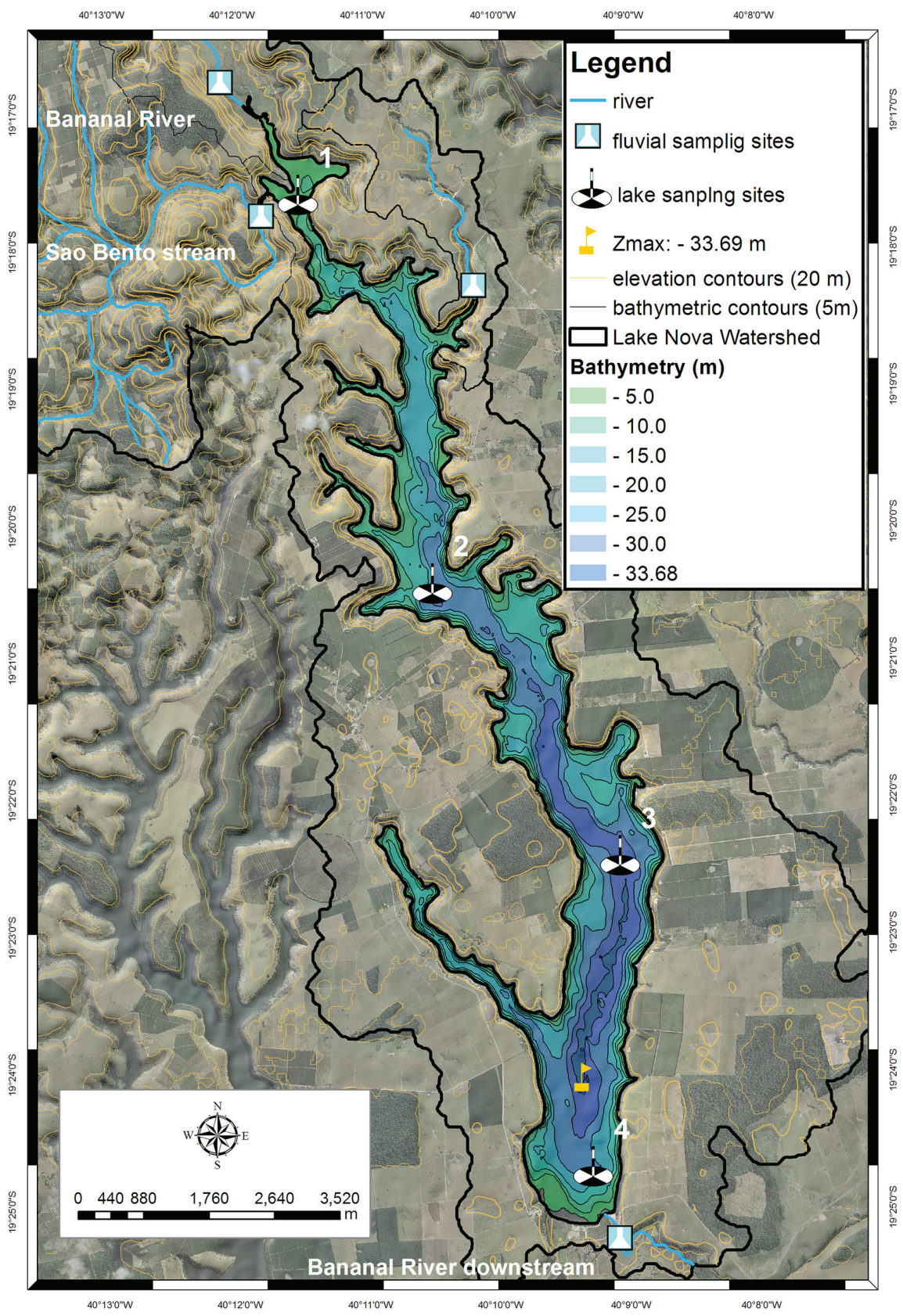

Figure 3 - Bathymetric map of Lake Nova draped on an aerial photography and showing lake and fluvial sampling sites.

TABLE I

Lake Nova size and form factors.

\begin{tabular}{cccccccccccc}
\hline Lake & $\mathrm{A}$ & $\mathrm{L}_{0}$ & $\mathrm{~L}_{\max }$ & $\mathrm{B}_{\max }$ & $\mathrm{Z}_{\max }$ & $\mathrm{V}$ & $\mathrm{Z}_{\mathrm{mv}}$ & $\mathrm{Z}_{\mathrm{r}}$ & $\mathrm{D}_{\mathrm{L}}$ & $\mathrm{V}_{\mathrm{d}}$ & $\mathrm{S}_{\mathrm{mv}}$ \\
\hline Nova & $\left(\mathrm{km}^{2}\right)$ & $(\mathrm{km})$ & $(\mathrm{km})$ & $(\mathrm{km})$ & $(\mathrm{m})$ & $\left(\mathrm{km}^{3}\right)$ & $(\mathrm{m})$ & $(\%)$ & & $(\%)$ \\
\hline & 15.5 & 70.4 & $\begin{array}{c}15.7 \\
(\mathrm{~S}-\mathrm{N})\end{array}$ & $\begin{array}{c}2.4 \\
(\mathrm{E}-\mathrm{W})\end{array}$ & 33.9 & 0.23 & 14.7 & 0.7 & 5.0 & 1.3 & 3.2 \\
& & & & & & & & \\
\hline
\end{tabular}

A: area; $\mathrm{L}_{0}$ : shoreline length; $\mathrm{L}_{\max }:$ maximum length; $\mathrm{B}_{\max }$ maximum breadth: $\mathrm{Z}_{\max }:$ maximum depth; $\mathrm{V}$ : volume; $\mathrm{Z}_{\mathrm{mv}}:$ mean depth; $\mathrm{Z}_{\mathrm{r}}$ : relative depth; $\mathrm{D}_{\mathrm{L}}$ : shoreline development index; $\mathrm{V}_{\mathrm{d}}$ : volume development index; $\mathrm{S}_{\mathrm{mv}}$ : mean slope. 
Alongside lake $\mathrm{N}-\mathrm{S}$ axis there are 13 indentation with depths up to $5 \mathrm{~m}$, with the exception of SW embayment in lower section of lake, which is 3.6 $\mathrm{km}$ long and has depths up to $20 \mathrm{~m}$. In the riverine influence zone, located at the northernmost section of the lake, depths are limited to $5 \mathrm{~m}$. Shallow areas are also located in the southern shore, with bottom depths shallower than $2 \mathrm{~m}$ colonized by aquatic grass. Deep basins (>20 m) are delimited by $20 \mathrm{~m}$ depth curve beginning from the second shoreline inflection, while the $30 \mathrm{~m}$ depth contour begins from the third inflection and extends up to $1.5 \mathrm{~km}$ to the South shore.

The moderate mean slope $\left(S_{m v}\right), 3.2 \%$, indicate a smooth topography, although in the slope map (Figure 2) steep slopes, up to $42 \%$, can be observed along parts of the shore with hills of Barreiras plateaus $(\sim 60 \mathrm{~m})$ to the lake surface $(22 \mathrm{~m})$. While overall smooth slope, Lake Nova basin can be considered as relative deep according to $Z_{r}$ of $0.7 \%$, $A / V$ ratio of $0.06, Z_{\max } 2.3$ times $Z_{m v}$ and $Z_{m v}: Z_{\max }$ ratio of 0.4 that indicate a paraboloid bottom contour.

\section{LAKE SPECIAL FACTORS}

The slight convex hypsographic volume curve (Figure 4) show that about $76 \%\left(1.74 \times 10^{8} \mathrm{~m}^{3}\right)$ of lake volume is within the first $10 \mathrm{~m}$ of depth, while less than $10 \%\left(0.49 \times 10^{8} \mathrm{~m}^{3}\right)$ is below 20 $\mathrm{m}$. Considering that lake surface is at $22 \mathrm{~m}$ above sea level and $Z_{\max }$ is $33.9 \mathrm{~m}$, lake cryptic depth $\left(Z_{c}\right)$

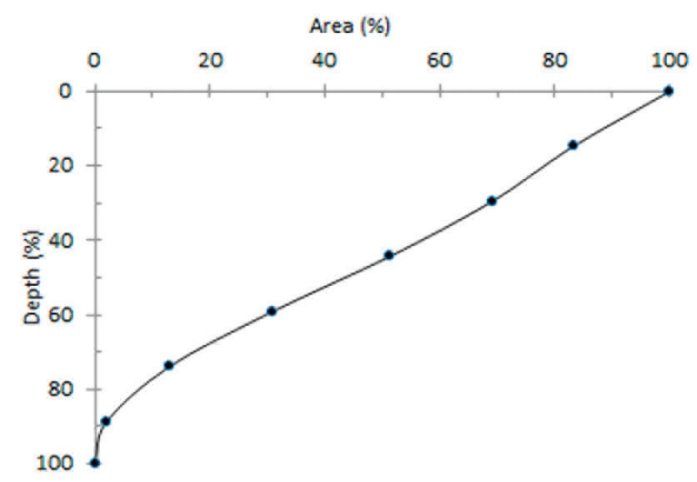

Figure 4 - Hypsographic curves of area and volume. is $11.9 \mathrm{~m}$, thus cryptic volume $\left(V_{c}\right)$ correspond to $64 \%\left(1.47 \times 10^{8} \mathrm{~m}^{3}\right)$ of lake volume.

Wind regime is characterized by wet/warm period associated with NE winds, while dry/cool period is related to S-SE winds from cold fronts, blowing up to $11.1 \mathrm{~m} / \mathrm{s}$ (Figures $5 \mathrm{a}$ and $5 \mathrm{~b}$ ). Wind effects on lake surface was estimated based on effective fetch $\left(L_{e f}\right)$, which varied from 0.01 to 0.6 $\mathrm{km}$ for NE winds and 0.01 to $0.5 \mathrm{~km}$ for SE winds. The $L_{e f}$ model for NE wind show higher influence on SW lake shores (Figure 5c), while during cold fronts, SE wind, most influenced areas lies between the second and third shoreline inflection and at the entrance of the SW embayment (Figure 5d). Wave height pattern follow the same patterns (Figures $5 \mathrm{e}$ and $5 \mathrm{f}$ ) with heights up to 0.5 to $0.8 \mathrm{~m}$ for $\mathrm{NE}$ and SE winds, respectively.

The estimate of wave base depth $\left(Z_{w b}\right)$ is $6.9 \mathrm{~m}$. The dynamic ratio $(D R)$ yield 0.2 , which according to Håkanson (2004) implies that about $15 \%$ of lake area is subjected to slope process with shoreline erosion and transport. The Index of Basin Permanence - IBP of $3.2 \mathrm{~m}^{3} \cdot \mathrm{km}^{-1}$ indicates that Lake Nova is less willing to develop a littoral zone with rooted aquatic vegetation. Based on $Z_{e u}$ of $9 \mathrm{~m}$ the area of littoral zone is $4 \mathrm{~km}^{2}$ or $26 \%$ of lake area, while pelagic area make $11.5 \mathrm{~km}^{2}$ or $74 \%$ (Figure 2). The volume of littoral zone $\left(V_{l i t}\right)$ is $4.5 \%(0.101$ x $\left.10^{8} \mathrm{~m}^{3}\right)$ while the pelagic volume $\left(V_{p e l}\right)$ holds $95.5 \%\left(2.18 \times 10^{8} \mathrm{~m}^{3}\right)$ of the total lake volume.

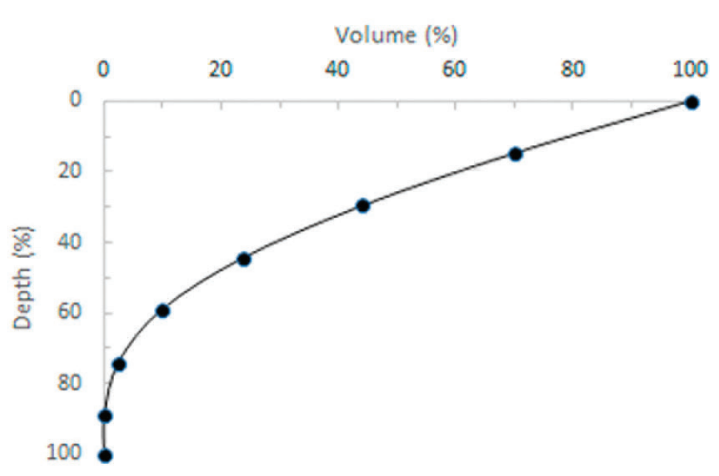




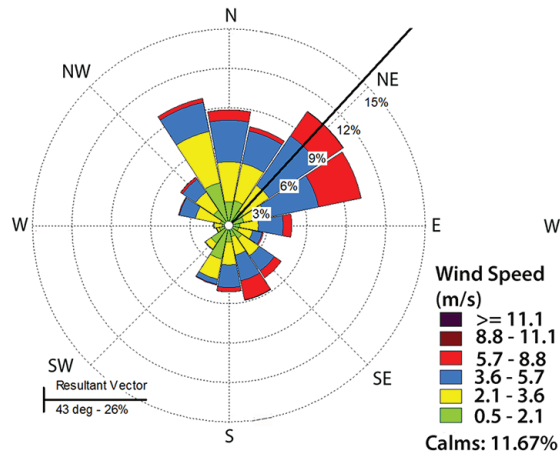

a)

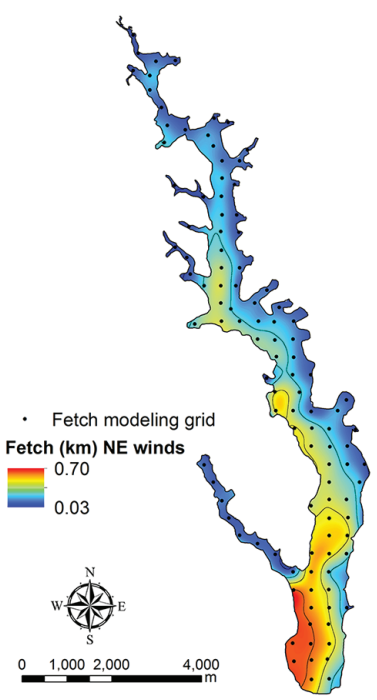

c)

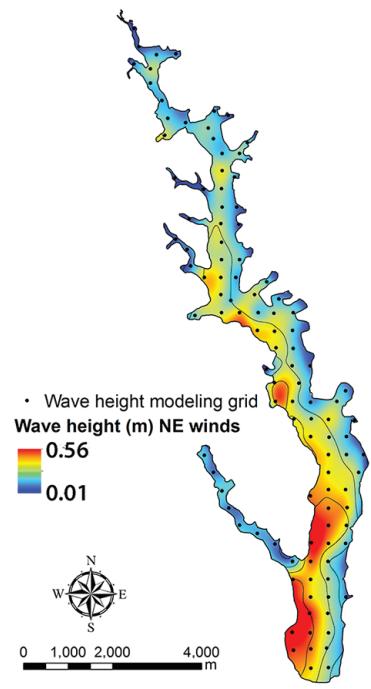

e)

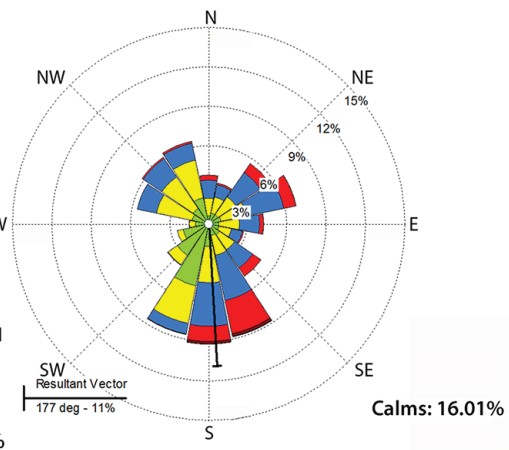

b)

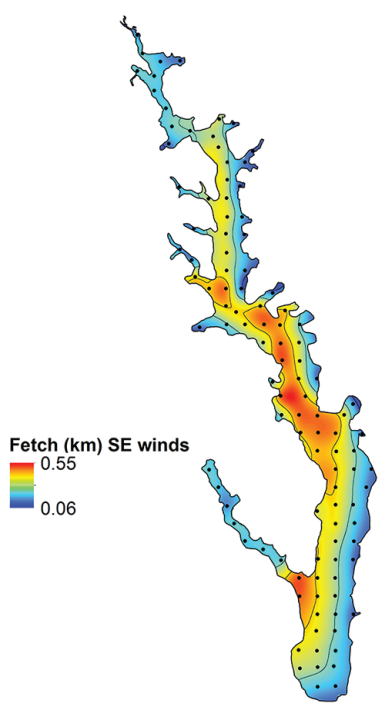

d)

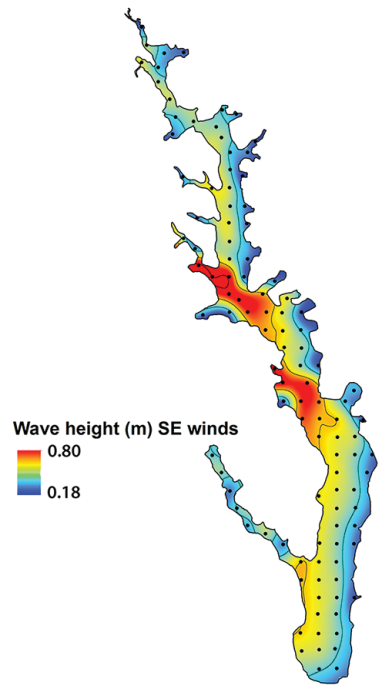

f)

Figure 5 - Wind roses for Linhares meteorological station (A614) based on hourly records for 2007 to 2009: a) wet and warm season and b) dry and cool season (Barroso et al. 2014). Fetch models: c) NE wind and d) SE wind. Wave height (m) models: e) NE Wind and f) SE wind. 
Lake Nova watershed drains an area $\left(W_{A}\right)$ of $394.6 \mathrm{~km}^{2}$, which may imply in significant inputs of nutrients to the lake, considering the relative high $W_{A}: A$ ratio of 25.8 and watershed land use. The mean annual discharge of the three tributary rivers is $0.5 \mathrm{~m}^{3} \cdot \mathrm{s}^{-1}$, consequently the theoretical retention time $(R T)$ of lake volume is 13.4 years. If mean discharges for dry/cool $\left(0.5 \mathrm{~m}^{3} . \mathrm{s}^{-1}\right)$ and wet/warm $(0.6$ $\left.\mathrm{m}^{3} \cdot \mathrm{s}^{-1}\right)$ seasons were considered, $R T$ would increase and decrease to 14.7 and 11.8 years, respectively.

\section{WATER COLUMN STRUCTURE}

Water column remain stratified during the wet and warm season at sample sites 2, 3 and 4 , with a temperature difference from surface to bottom up to $6{ }^{\circ} \mathrm{C}$ and mean thermal stability measured with a mean Wedderburn number of $3.5 \pm 1.6$ (Figure 6 and Table II). Under this condition mean $Z_{\text {mix }}$ was $7 \pm 3.4 \mathrm{~m}$, which is very close to the depth of wave base $\left(Z_{w b}\right), 6.9 \mathrm{~m}$, indicating the extension of water

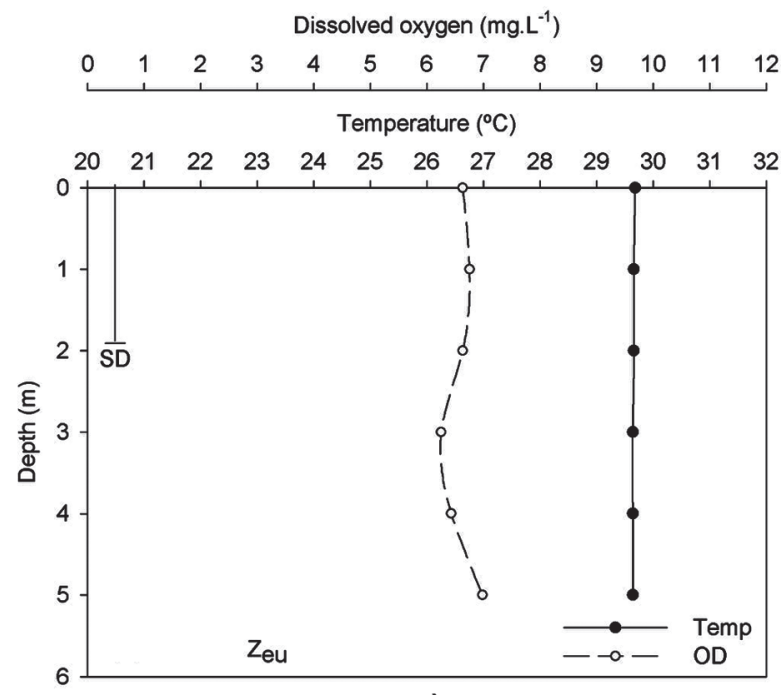

a)

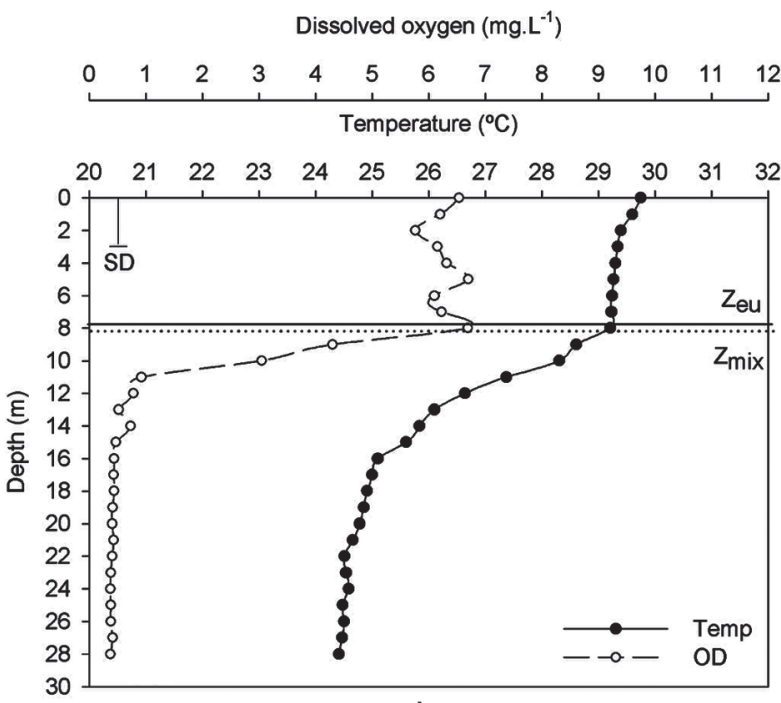

c)

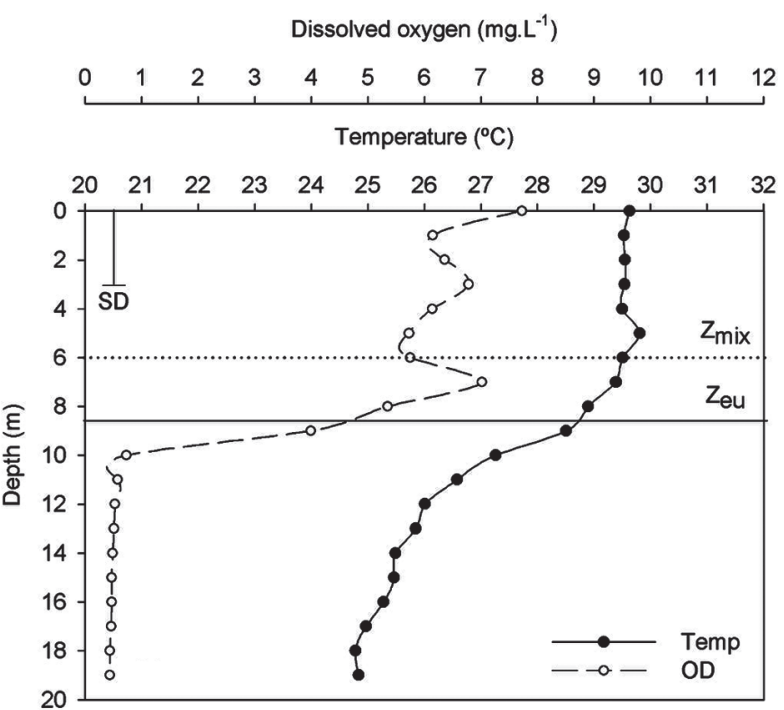

b)

Dissolved oxygen (mg. $\left.\mathrm{L}^{-1}\right)$
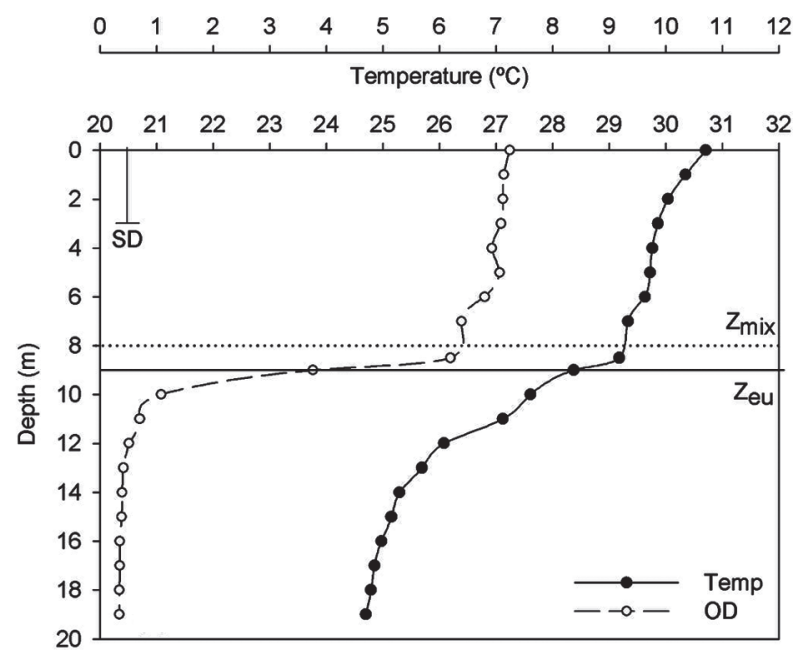

d)

Figure 6 - Vertical profiles of temperature $\left({ }^{\circ} \mathrm{C}\right)$ and dissolved oxygen $\left(\mathrm{mg} . \mathrm{L}^{-1}\right)$ Secchi disk depth $(\mathrm{m})$, mixing depth $\left(\mathrm{Z}_{\text {mix }}\right)$ and euphotic depth $\left(Z_{\text {eu }}\right)$ in four sampling sites of Lake Nova, during wet and warm season (e.g, March 2012): a - sampling site 1; b site $2 ; \mathbf{c}-$ site $3 ; \mathbf{d}$ - site 4 . Note: different depth scales. 
TABLE II

Descriptive statistics for physical and physic-chemical variables in water column.

\begin{tabular}{|c|c|c|c|c|c|c|}
\hline & $\begin{array}{l}\text { Temp } \\
\left({ }^{\circ} \mathrm{C}\right)\end{array}$ & $\begin{array}{l}Z_{\text {mix }} \\
(\mathrm{m})\end{array}$ & W & $\begin{array}{l}\text { SD } \\
(\mathrm{m})\end{array}$ & $\begin{array}{l}Z_{\mathrm{eu}} \\
(\mathrm{m})\end{array}$ & $\begin{array}{c}\text { DO } \\
\left(\mathrm{mg} \cdot \mathrm{L}^{-1}\right)\end{array}$ \\
\hline \multicolumn{7}{|c|}{ Wet and warm season } \\
\hline Average & 26.6 & 6.9 & 4,6 & 3.1 & 9.1 & 4.6 \\
\hline Min & 22.4 & 1.0 & 0.0 & 1.2 & 3.6 & 0.3 \\
\hline $\operatorname{Max}$ & 30.9 & 14.0 & 23.1 & 4.8 & 14.5 & 10.0 \\
\hline Range & 8.6 & 13.0 & 23.1 & 3.6 & 10.9 & 9.8 \\
\hline SD & 0.8 & 3.4 & 4.9 & 0.9 & 3.5 & 1.1 \\
\hline $\mathrm{VC}(\%)$ & 2.9 & 50.1 & 134.4 & 29.8 & 38.5 & 24.4 \\
\hline \multicolumn{7}{|c|}{ Dry and cool season } \\
\hline Average & 22.7 & 16.2 & 0.0 & 3.5 & 9.9 & 10.0 \\
\hline Min & 21.2 & 3.0 & 0.0 & 1.8 & 4.0 & 4.1 \\
\hline $\operatorname{Max}$ & 25.9 & 29.0 & 0.0 & 4.8 & 14.4 & 18.9 \\
\hline Range & 4.7 & 26.0 & 0.0 & 3.0 & 10.4 & 14.8 \\
\hline SD & 1.4 & 8.8 & 0.0 & 0.8 & 3.4 & 2.0 \\
\hline VC (\%) & 6.0 & 54.1 & 0.0 & 23.1 & 33.7 & 19.8 \\
\hline
\end{tabular}

column subject to wave turbulence and sediments resuspension. Considering the mean $Z_{\text {mix }}$ and $Z_{w b}$ the volume of epilimnetic waters $\left(V_{e p}\right)$ contain $59 \%$ of lake volume $\left(1.35 \times 10^{8} \mathrm{~m}^{3}\right)$, while bottom volume hold the other $41 \%\left(0.93 \times 10^{8} \mathrm{~m}^{3}\right)$.

During wet and warm season the mean euphotic zone, delimited by $1 \%$ of subsurface light $\left(Z_{e u}\right.$ reaches $9 \mathrm{~m}$ depth) yielding an euphotic volume $\left(V_{e u}\right)$ of $51 \%$ of lake volume $\left(1.17 \times 10^{8}\right.$ $\left.\mathrm{m}^{3}\right)$, while the other $49 \%\left(1.06 \times 10^{8} \mathrm{~m}^{3}\right)$ holds the aphotic volume. For this season $Z_{e u}: Z_{m i x}$ ratio was 1.3 , while in the dry and cool season, when eventual stratification is weaker, yields only 0.6. That implies in light limitation for phytoplankton primary productivity during the later season, as phytoplankton can be trapped in the dark.

Profiles of dissolved oxygen during wet and warm season show a clear trend to hypoxic $(<2.0$ mg. $\left.\mathrm{l}^{-1}\right)$ and anoxic bottom waters, with the decline of dissolved oxygen at the end of thermocline, $13 \mathrm{~m}$ depth. Considering this depth $35 \%$ of lake volume $\left(0.8 \times 10^{8} \mathrm{~m}^{3}\right)$ can be considered as poor or depleted in dissolved oxygen.
Throughout dry and cool season temperature profiles have shown low variability with Wedderburn number yielding zero value indicating mixing conditions (Table II and Figure 7). Dissolved oxygen profiles shown slight stratification but without bottom hypoxia.

Sampling site 1, which lies under the fluvial influence of River Bananal, the main tributary for Lake Nova, have shown through both seasons mixed water column (Wedderburn number $=0$ ). Homogeneous dissolved oxygen profiles and $Z_{e u}$ extending to lake bottom were also registered throughout the sampling seasons.

\section{DISCUSSION}

Deep tropical lakes show a trend of monomictic and amictic mixing patterns (Lewis 1983). Although Brazilian natural lakes are usually shallow systems, some lakes in the Doce River Valley - DRV, such as Lake Dom Helvécio (Bezerra-Neto and PintoCoelho 2008), Lake Palminhas (Barroso et al. 2012), and Lake Palmas (Barroso et al. 2014) are deep $(<50 \mathrm{~m}$ depth), showing a monomictic mixing pattern, which also match Lake Nova pattern. 


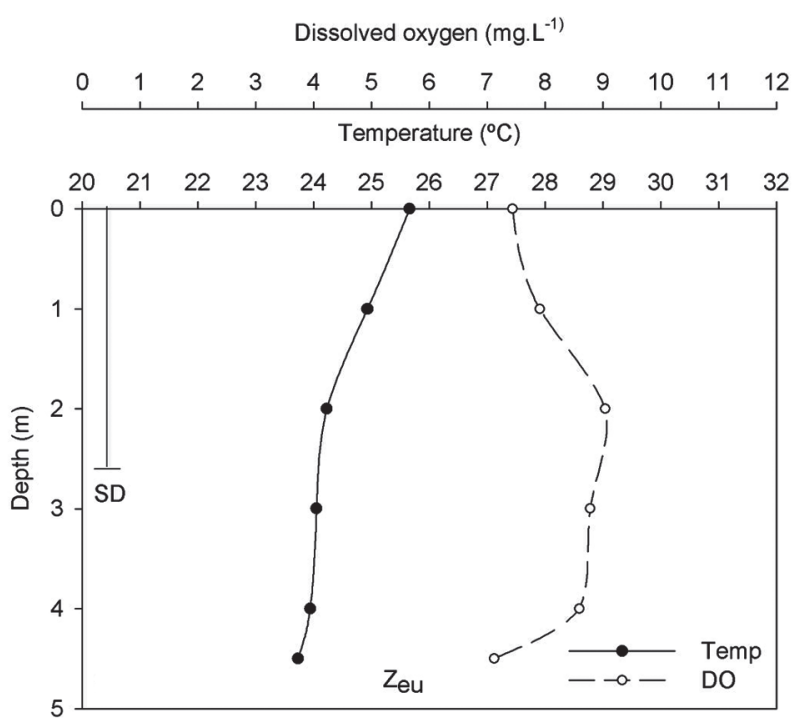

a)

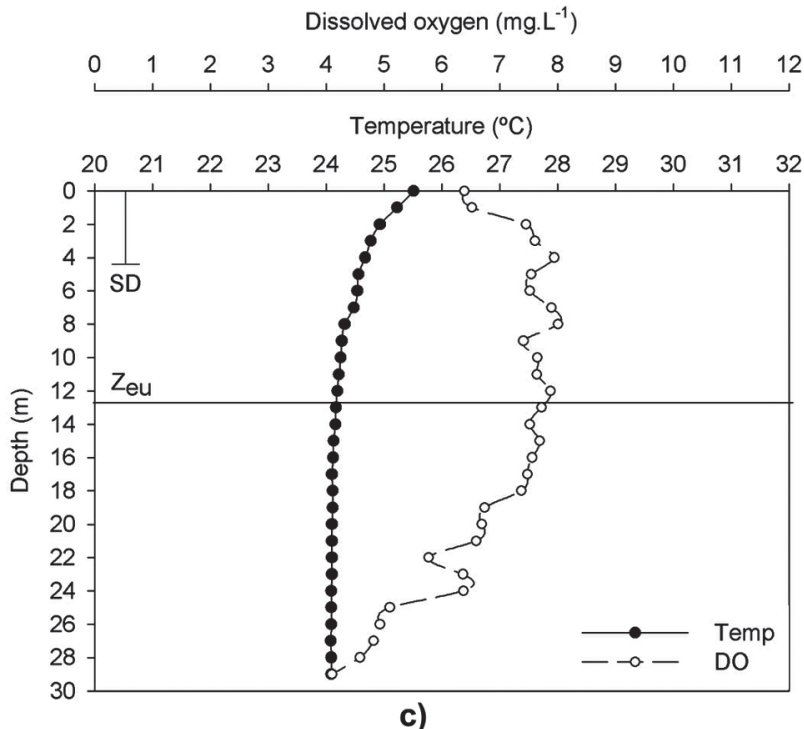

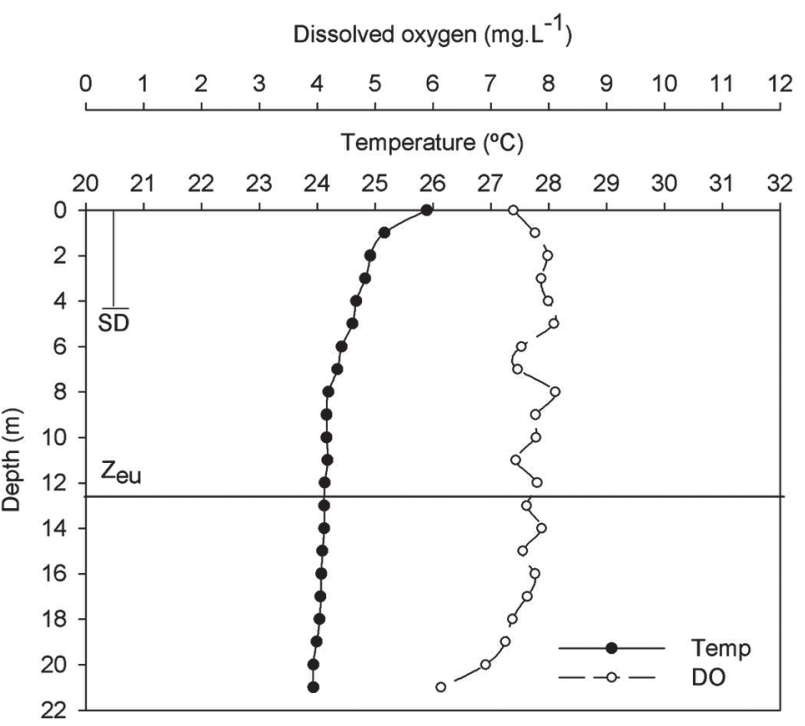

b)

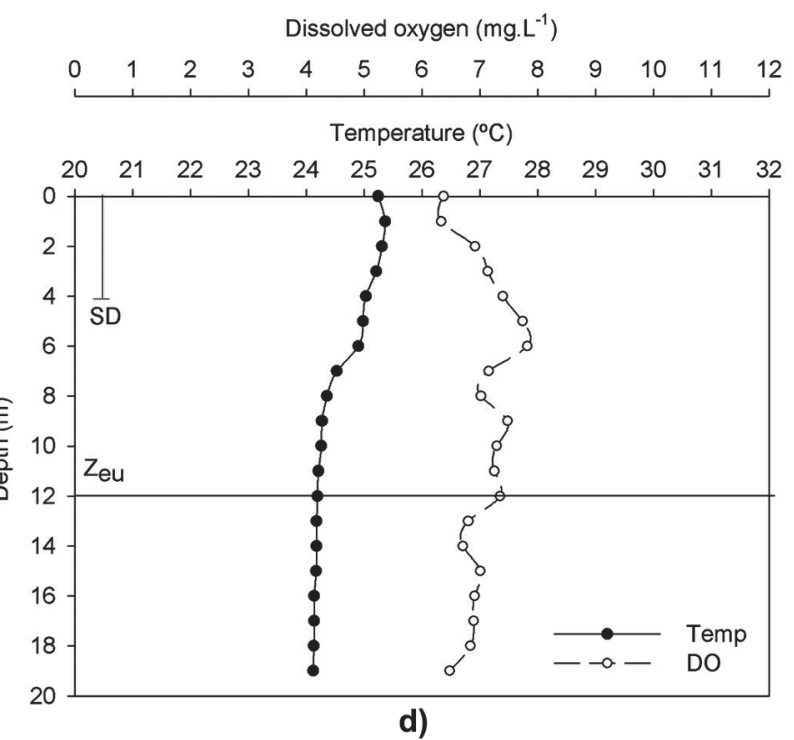

Figure 7 - Vertical profiles of temperature $\left({ }^{\circ} \mathrm{C}\right)$ and dissolved oxygen $\left(\mathrm{mg} . \mathrm{L}^{-1}\right)$ Secchi disk depth $(\mathrm{m})$, mixing depth $\left(\mathrm{Z}_{\text {mix }}\right)$ and euphotic depth $\left(\mathrm{Z}_{\text {eu }}\right)$ in four sampling sites of Lake Nova, during dry and cool season (e.g, July 2012): a - sampling site 1; b - site 2 ; $\mathbf{c}$ - site $3 ; \mathbf{d}$ - site 4 . Note: different depth scales.

The subretangular elongated shape, N-S oriented, slightly dendritic with several indentations, and a slight linear bottom hypsography with moderate slope is in accordance to its fluvial and neotectonic genesis of alluvial lakes in the LDRV. The former process is related with the damming of River Bananal (Martin et al. 1996), while the later may explain the overdeepened valley, such as the case of Lakes Palmas and Nova, which may be as- sociated with tectonic faults (Hatushika et al. 2007, Bricalli and Mello 2013). Among shape morphometric factors, $D_{L}$ of 5.0 for Lake Nova is in the intermediate range for the LDRV lakes such as Terra Alta, Juparanã, Palmas and Palminhas, with 3.1, 3.9, 4.3 and 8.1, respectively (Barroso et al. 2012).

The values of $Z_{\max }(33.9 \mathrm{~m})$ and $Z_{m v}(14.7)$ of Lake Nova are significant high in relation to other Brazilian lakes. Among 61 coastal lakes of Rio 
Grande do Sul State, South of Brazil, the deepest two lakes shown $Z_{\max }$ of $11 \mathrm{~m}$. Comparing with the two deepest natural lake in Brazil, Lake Palmas ( $Z_{\max }$ of $50.7 \mathrm{~m}$ and $Z_{m v}$ of $21.4 \mathrm{~m}$ ) at the LDRV (Barroso et al. 2014), and Lake Dom Helvécio ( $Z_{\max }$ of $39.3 \mathrm{~m}$ and $Z_{m v}$ of $11.3 \mathrm{~m}$ ) at the MDRV (Bezerra-Neto and Pinto-Coelho 2008), Lake Nova can be considered the third in $Z_{\max }$, but the second one considering $Z_{m v}$. This is also valid considering lake volumes. The significant $Z_{c}$ and the high $V_{c}$ are related with the lake geomorphology, which was associated with fluvio-marine processes (Martin et al. 1996).

Hypsographic curves with a linear shape for area and slightly convex for volume, likewise moderate $Z_{r}, V_{d}, Z_{m v}: Z_{\max }, I B P$ and $D R$, low $A / V$ ratio, and $Z_{\max } 2.3$ times $Z_{m v}$ describe a relative deep basin with paraboloid bottom contour. As a result, the basin has a relative small littoral zone, with $26 \%$ of lake area corresponding to only $4 \%$ of lake volume.

Moderate steep shores of Barreiras plateau, as indicated by paraboloid bottom contour, may overcome turbulence process by wind and wave, prevailing process of erosion and transport of sediments. As overall indicator of sediment resuspension $Z_{w b}$ of $(6.9 \mathrm{~m})$ prevent turbulence on sediments, reducing turbidity and improving water clarity in great part of Lake Nova (mean Secchi disk depths of $3.1 \pm 0.9 \mathrm{~m})$. The effective fetch $\left(L_{e f}\right)$ is higher for cold front winds, blowing from S-SE. Under this condition the most influenced section is between the second and third lake axis inflections. As this area is deep with steep shores, sediments resuspension does not occur.

The relative deep basin with limited littoral effects on basin volume complies with thermal stability of water column, as it has been shown with thermal profiles during the wet and warm season. Even though high $L_{e f}$ for this season, predominant NE wind work was not effective to promote a deep turbulence in water column. Wedderburn numbers, calculated for each sampling site at every sampling event, were very high during warm and wet season, indicating a strong resistance to mixing. Under these conditions $Z_{w b}$, as an indicator to distinguish surface waters from deep waters, corresponds to $Z_{m i x}$. Consequently, about $41 \%$ of lake volume in the mixing layer receives most of thermal energy.

The riverine zone of the main tributary (River Bananal, sampling site 1), is completely distinct form sampling sites 2, 3 and 4 . The shallow area $(<3.0 \mathrm{~m})$ is subject to turbulence of wind and fluvial flow, therefore water column stratification and hypoxia seldom occur at this part of the lake, which can be regarded as a riverine zone according to the concept of longitudinal zonation (Kimmel et al. 1990). Sampling sites 2 to 4 are related to a lacustrine zone, where thermal stratification occurs. In this zone thermal and density gradients along water column control the distribution of chemical compounds. The extent and duration of water column stratification is a seasonal process related to climate.

Chemical stratification is also a common feature for the stratified condition in Lake Nova. Hypoxic/anoxic conditions start at the end of thermocline, at the depth of $13 \mathrm{~m}$, representing up to $35 \%$ of lake volume. This implies into a key process of solubility of nutrients form sediment porewater to hypolimninetic waters (Cole 1994, Wetzel 2001, Conley et al. 2009). Although water column stratification is characteristic of the wet and warm summer season it may last for the transition seasons of autumn and spring. Therefore, areal hypolimnetic oxygen deficit may become a key control for nutrient internal loading to Lake Nova.

During dry and cool season water column is unstable with lake mixing as a consequence of atmosphere cooling and increasing incidence of cold fronts with S-SE winds, which causes high $L_{e f}$ and wave height $(H)$. The homogeneous water column distributes dissolved oxygen in bottom waters, thus preventing diffusion of nutrients to bottom waters 
owing to oxidizing surface sediments porewater (Mortimer 1971, Conley et al. 2009).

Regarding the influence of drainage basin on Lake Nova, the ratio $W_{A}$ :A of 25.8 is relative high compared to other LDRV Lakes such as Palminhas (8) and Palmas (18), but lower in contrast to Terra Alta (37) and Juparanã (39) (Barroso et al. 2012). This has major implications on lake structure and functioning, mainly in relation to fluvial tributary inputs of water and dissolved and suspended materials.

Higher $W_{A}: A$ ratios imply in higher fluvial inputs, so lake water tend to be rich in nutrients and organic matter, with high $\mathrm{pH}$, conductivity and alkalinity (Nõges 2009). However, in deep basin lakes with longer retention time, chlorophyll content is lower and water clarity is higher. This seems to be the case of Lake Nova in which mean chlorophyll $a$ is very low, $<1.0 \mu \mathrm{g} \mathrm{L}^{-1}$ according to Bozelli et al. (1992) and $1.5 \pm 0.7 \mu \mathrm{g} \mathrm{L}^{-1}$ according to M.A. Gonçalves (unpublished data). The oligotrophic status can be a consequence of nutrients trapped in hypolimnetic waters, and phytoplankton light limitation during the mixing season, when $Z_{e u}: Z_{m i x}<1.0$.

Watershed hydrology also influences lake longitudinal zonation with river discharge in the lake controlling water retention time (Ambrosetti et al. 2003, Nõges et al. 2011). With a mean annual fluvial input of $0.5 \mathrm{~m}^{3} \cdot \mathrm{s}^{-1}$ Lake Nova theoretical retention time (RT) is estimated in 13.4 years. This seems to be a long RT compared with the average of $5.5 \pm 17.9$ years for 310 European lakes (Nõges 2009). Even large lakes may show short RT, such as Lake Maggiore $\left(\mathrm{A}=212.5 \mathrm{~km}^{2}, \mathrm{Z}_{\text {max }}=370 \mathrm{~m}\right.$; $\mathrm{Z}_{\mathrm{mv}}=177 \mathrm{~m}, \mathrm{~V}=37.1 \mathrm{~km}^{3}$ and $W_{A}: A$ ratio of 31.1$)$, a subalpine lake between Italy/Switzerland, has a RT of only 4 years (Ambrosetti et al. 2003). In the case of Lake Nova it appears that the long RT is due to low hydrological input by the tributary rivers.

Although Lake Nova watershed can be considered a well drained basin (drainage density of $1.5 \mathrm{~km} \cdot \mathrm{km}^{-2}$ ), the intensive water and land use may exert significant controls on fluvial inputs. According to Barroso and Mello (2013) about $70 \%$ of lake watershed is composed by seminatural systems (i.e., pastureland, cropland and forestry). Besides the intensive land use 44 impoundments (0.3 $\mathrm{km}^{2}$ of impoundments), most of them for irrigation uses, are located in the Lake Nova watershed.

Therefore, the compromised natural vegetation buffer of rivers and lake in addition to the river network fragmentation and regularization can drive hydrological changes in quantity, quality and timing of fluvial inputs, which in turn reduce lake flushing capacity and increase physical and chemical lake stratification. This scenario of environmental changes may be chiefly severe under extreme hydrological events.

\section{CONCLUSIONS}

Lake Nova basin is a subrectangular elongated and relatively deep, with limited littoral influence on pelagic processes. Based on mean depth $\left(Z_{m v}\right)$ Lake Nova can be considered the second deepest natural lake in Brazil. The deep tropical basin promote water column thermal stability with a warm monomictic mixing pattern with stratification on warm and wet season and mixing during dry and cool season. This pattern is in agreement of other deep tropical Brazilian lakes. During the stratification season bottom waters become hypoxic and anoxic, holding up to $1 / 3$ of lake volume. The effect of wind work is restricted to eplimnetic layer depth, which was estimated with thermal profiles and wave base depths. Water column turbulence related to sediment resuspension is limited. Lake Nova water clarity promotes penetration of photosynthetic active radiation in the water column, with half of lake volume within the euphotic zone. However, during the dry and cool season, when eventual weaker stratification may develop, mixing 
depths can be deeper than the euphotic layer, thus phytoplankton can be limited by light availability.

The relative long theoretical retention time of 13.4 years and the relative deep basin, although intensive land and water uses in watershed, may induce environmental chances in terms of hydrological flows to the lake, thus increasing its retention time.

\section{REFERENCES}

AMBROSETTI W, BARBANTI L AND SALA N. 2003. Residence time and physical processes in lakes. J Limnol 62(1): 1-15.

BARBOSA FAR, LOVATO MB, NASCIMENTO AMA, MAIA-BARBOSA PM, MONTE-MOR RL, PAGLIA A AND STEHMANN JR. 2013. Dinâmica Biológica e Conservação da Biodiversidade da Mata Atlântica do Médio Rio Doce, MG (PELD/UFMG). In: Tabarelli M, Rocha CFD, Romanowski HP, Rocha O and Lacerda LD (Eds), PELD - CNPq: dez anos do Programa de Pesquisas Ecológicas de Longa Duração do Brasil: achados, lições e perspectivas. Recife: Ed. Universitária da UFPE, 446 p.

BARROSO GF. 2007. Lagoas costeiras do Espírito Santo: perspectivas para conservação. Menezes LFT, Pires FR and Pereira OJ (Eds), Ecossistemas costeiros do Espírito Santo: conservação e restauração. Vitória, EDUFES, p. 71-86.

BARROSO GF, GARCIA FC, GONÇALVES MA, MARTINS FCO, VENTURINI JC, SABADINI SC, AZEVEDO AK, FREITAS ACT, DELAZARI-BARROSO A AND BERTOLDI L. 2012. Estudos integrados no sistema lacustre do Baixo Rio Doce (Espírito Santo). In I Seminário Nacional de Gestão Sustentável de Ecossistemas Aquáticos: Complexidade, Interatividade e Ecodesenvolvimento, COPPE/UFRJ.

BARROSO GF, GONÇALVES MA AND GARCIA FC. 2014. The Morphometry of Lake Palmas, a Deep Natural Lake in Brazil. PLoS One 9(11): e111469.

BARROSO GF AND MELLO FA. 2013. Compartimentação da paisagem e indicadores de pressões ambientais em ecossistemas lacustres e fluviais na região do Baixo Rio Doce (ES). Anais do XV Simpósio Brasileiro de Geografia Física Aplicada. Vitória, UFES, p. 158-165. Available at http://www.xvsbgfa2013.com.br/anais/.

BEZERRA-NETO JF AND PINTO-COELHO RM. 2008. Morphometric study of lake Dom Helvécio, Parque Estadual do Rio Doce (PERD), Minas Gerais, Brazil: a reevaluation. Acta Limnol Bras 20(2): 161-167.

BOZELLI RL, ESTEVES FA, ROLAND F AND SUZUKI MS. 1992. Padrões de funcionamento das lagoas do Baixo
Rio Doce: variáveis abióticas e clorofila $a$ (Espírito Santo - Brasil). Acta Limnol Bras 4: 13-21.

BRICALLI LL AND MELLO CL. 2013. Padrões de lineamentos relacionados a litoestrutura e faturamento neotectônico (Estado do Espírito Santo, SE do Brasil). Rev Bras de Geom 14: 301-311.

BURROUGH PAAND MACDONNELL RA. 1998. Principles of geographical informations systems. Oxford, Oxford University Press, 333 p.

COLE GA. 1994. Textbook of Limnology. $4^{\text {th }}$ ed., Prospect Heights, Illinois: Waveland Press, $412 \mathrm{p}$.

CONLEY DJ, CARSTENSEN J, VAQUER-SUNYER R AND DUARTE CM. 2009. Ecosystem thresholds with hypoxia. Hydrobiologia 629(1): 21-29.

DADON JR. 1995. Calor y temperatura em cuerpos lenticos. In: Lopretto EC and Tell G. Ecosistemas de aguas continentales: metodologias para su estúdio. La Plata, Ediciones SUR 1: 47-56.

HÅKANSON L. 2004. Lakes: form and function. Cladwell, The Blackburn Press, $201 \mathrm{p}$.

HÅKANSON L. 2005. The importance of lake morphometry and catchment characteristics in limnology - ranking based on statistical analyses. Hydrobiologia 541(1): 117-137.

HATUSHIKA RS, SILVA CG AND MELLO CM. 2007. Sismoestratigrafia de alta resolução no lago Juparanã, Linhares (ES-Brasil) como base para estudos sobre a sedimentação e tectônica quaternária. Rev Bras Geof 25(4): 433-442.

HENRY R, PONTES MCF AND TUNDISI JG. 1989. O déficit de oxigênio no Lago Dom Helvécio (Parque Estadual do Rio Doce, Minas Gerais). Braz J Biol 49(1): 251-260.

HUTCHINSON GE. 1957. A treatise on limnology. Volume I: Geography, physics and chemistry. New York, J Wiley \& Sons, Inc., $115 \mathrm{p}$.

IMBERGER J AND HAMBLING PF. 1982. Dynamics of lakes, reservoirs and cooling ponds. Annu Rev Fluid Mech 14: 153-187.

ISAKS EH AND SRIVASTAVA RM. 1989. Applied geostatistics. Oxford, Oxford University Press, 561 p.

JENSEN P, JEPPESEN E, OLRIK K AND KRISTENSEN K. 1994. Impact of nutrients and physical factors on the shift from cyanobacterial to chlorophyte dominance in shallow Danish lakes. Can J Fish Aquat Sci 51: 1692-1699.

KEREKES J. 1977. The index of lake basin permanence. Intern. Revue Hydrobiol Hydrogr 62(2): 291-293.

KIMMEL BL, LIND OT AND PAULSON LJ. 1990. Reservoir primary production. In: Thornton KW, Kimmel BL and Payne FE (Eds), Reservoir Limnology: Ecological Perspectives. New York: J Wiley \& Sons, Inc., 245 p.

LEWIS WM. 1983. A revised classification lakes based on mixing. Can J Fish Aquat Sci 40: 1779-1787.

MARTIN L, SUGUIO K, FLEXOR JM AND ARCHANJO JD. 1996. Coastal Quaternary formations of the Southern 
part of the state of Espírito Santo (Brazil). An Acad Bras Cienc 68: 389-404.

MORTIMER CH. 1971. Chemical exchanges between sediments and water in the Great Lakes - speculations on probable regulatory mechanisms. Limnol Oceanogr 16: 387-404.

NASELLI-FLORES L. 2000. Phytoplankton assemblages in twenty-one sicilian reservoirs: relationships between species composition and environmental factors. Hydrobiologia 424: 1-11.

NÕGES T. 2009. Relationships between morphometry, geographic location and water quality parameters of European lakes. Hydrobiologia 633: 33-43.
NÕGES P, NÕGES T, GHIANI M, PARACCHINI B, GRANDE JP AND SENA F. 2011. Morphometry and trophic state modify the thermal response of lakes to meteorological forcing. Hydrobiologia 667: 241-254.

REYNOLDS CS. 2006. The Ecology of Phytoplankton (Ecology, Biodiversity and Conservation).Cambridge University Press, Cambridge, 537 p.

SCHWARZBOLD A AND SCHÄFER A. 1984. Gênese e morfologia das lagoas costeiras do Rio Grande do Sul Brasil. Amazoniana 9(1): 87-104.

WETZEL RG. 2001. Limnology: lake and rivers ecosystems. Elsevier Academic Press, 1006 p. 